\title{
SUBSTANTIATION FOR SELECTING A PRESERVATIVE WHEN DEVELOPING THE GEL WITH ESSENTIAL OILS FOR TREATING DISEASES OF THE UPPER RESPIRATORY TRACT
}

\author{
V.V.Pul-Luzan, O.P.Strilets, T.V.Martynuk \\ National University of Pharmacy \\ Key words: preservative; gel with essential oils; microbiological purity; method for evaluating the \\ effectiveness of preservatives
}

\begin{abstract}
Based on the results of the microbiological research the necessity of introduction of a preservative into the gel with essential oils developed for treating diseases of the upper respiratory tract has been proven. The microbiological research has been conducted according to the conventional method of the SPhU with the gel samples, in which the following preservatives were added: sodium benzoate, methylparaben, the complex preservative "Germaben", the complex of sodium benzoate with Nipagin in the ratio of 0.5:0.1. It has been found that all gel samples under study meet of the SPhU requirements for microbiological purity (according to the criterion "A" and " $B$ "). While conducting the comparative analysis it has been determined that addition of the preservative complex of sodium benzoate with Nipagin in the ratio of 0.5:0.1 is the most effective.
\end{abstract}

At present there is a tendency to use topical drugs with a high aqueous phase content (creams water/oils, gels). However, these drugs are a favourable environment for microbial growth (cultures of $S$. aureus, PS. aeruginosa) or spoiling of finished products (culture of mold fungi, yeast fungi of the Candida genus) $[3,5,7]$.

As a result of the comprehensive research the composition of a gel with essential oils for treating diseases of the upper respiratory tract have been developed [6]. Due to the fact that the gel developed should be stable, including its microbiological purity value, at least for 2 years, it is necessary to study the microbiological purity of this gel and select the optimal preservative and its desired concentration $[4,5,6]$.

It is known that when selecting a preservative the attention should be paid to the therapeutic effect of the drug, its area of application, interactability with other ingredients of the formulation, and its solubility. Based on the literature search in order to select an effective preservative (or their combination), which is able to provide the quality and safety of the gel with essential oils developed, we studied the antimicrobial activity of the experimental samples of gels with different preservatives. The following preservatives were selected for the studies: sodium benzoate, methylparaben (Nipagin, methyl ether of $n$-4-hydroxybenzoic acid), and the complex of sodium benzoate with Nipagin. The complex preservative "Germaben" was also studied, it included diazolidinyl urea, methylparaben, and propylparaben in propylene glycol $[2,8,10]$.

Materials and Methods

The following gel samples were prepared: with $0.5 \%$ sodium benzoate (sample No. 1), with $0.1 \%$ methylparaben (sample No. 2), with $0.5 \%$ "Germaben" (sample
No. 3), with the complex of sodium benzoate and Nipagin $(0.5 \%: 0.1 \%)$ (sample No. 4$)$, and the sample without a preservative (sample No. 5).

During the studies the method for evaluating the effectiveness of antimicrobial preservatives given in the State Pharmacopoeia of Ukraine (SPhU) was used [4].

The culture media used in the study were standard manufactured by "Scientific Production Association Culture Media" (Mahachkala). The culture media were prepared according to the requirements of the manufacturer (the amount of the powder per litre, $\mathrm{pH}$ medium, autoclaving conditions, etc.). Each batch used in the experiment was tested for growth characteristics in compliance with regulations $[1,9]$.

Before the study there was a test conducted for conformity of the growth properties of the culture media (colony count grown when inoculating the microbial count). The culture media were inoculated with a small amount of the corresponding microbial test strains $\left(10-10^{2}\right.$ co-

Table 1

The study of the microbiological purity of the gel samples

\begin{tabular}{|c|c|c|}
\hline \multirow{2}{*}{$\begin{array}{c}\text { Samples } \\
\text { of gels }\end{array}$} & \multicolumn{2}{|c|}{$\begin{array}{c}\text { Culture media and conditions } \\
\text { Drug dilution in buffer } 1: 5\end{array}$} \\
\cline { 2 - 3 } & $\begin{array}{c}\text { thioglycolic acid } \\
\text { medium } \\
28 \text { days at } 35^{\circ} \mathrm{C}\end{array}$ & $\begin{array}{c}\text { liquid Saburo medium } \\
28 \text { days at } 25^{\circ} \mathrm{C}\end{array}$ \\
\hline No. 1 & The growth is absent & The growth is absent \\
\hline No. 2 & - -" $^{-}$ & - -- \\
\hline No. 3 & - -- & - -"- \\
\hline No. 4 & - -- & - -"- \\
\hline No. 5 & Microbial growth & \\
\hline
\end{tabular}


The study of the antibacterial activity of the gel samples with the preservative complex of sodium benzoate with Nipagin

\begin{tabular}{|c|c|c|c|c|c|}
\hline \multirow[b]{2}{*}{ Exposition } & \multicolumn{2}{|c|}{ The SPhU requirements } & \multicolumn{3}{|c|}{ The microbial count (CFU/ml), * Lg decrease } \\
\hline & $\begin{array}{c}\text { the bacterial } \\
\text { count (CFU/ml), } \\
\text { Lg decrease }\end{array}$ & $\begin{array}{l}\text { the number of } \\
\text { fungi }(\mathrm{CFU} / \mathrm{ml}), \\
\text { Lg decrease }\end{array}$ & $\begin{array}{c}\text { Staphylococcus } \\
\text { aureus } \\
\text { ATCC } 6538\end{array}$ & $\begin{array}{c}\text { Pseudomonas } \\
\text { aeruginosa } \\
\text { ATCC } 9027 \\
\end{array}$ & $\begin{array}{c}\text { Candida albicans } \\
\text { ATCC 885/653 }\end{array}$ \\
\hline Microbial load & $10^{6}$ & $10^{6}$ & $\begin{array}{c}3.5 \times 10^{5} \\
* 5.54\end{array}$ & $\begin{array}{c}4.5 \times 10^{5} \\
* 5.66 \\
\end{array}$ & $\begin{array}{c}2.2 \times 10^{5} \\
* 5.34\end{array}$ \\
\hline First inoculation $\mathrm{Lg}$ & - & - & $\begin{array}{c}4.9 \times 10^{4} \\
{ }^{*} 0.85\end{array}$ & $\begin{array}{c}5.1 \times 10^{4} \\
{ }^{*} 0.96\end{array}$ & $\begin{array}{c}5.2 \times 10^{4} \\
{ }^{*} 0.63\end{array}$ \\
\hline 2 days & 2 & - & $\begin{array}{c}3.3 \times 10^{3} \\
* 2.02\end{array}$ & $\begin{array}{c}2.7 \times 10^{3} \\
* 2.23\end{array}$ & $\begin{array}{c}1.3 \times 10^{4} \\
* 1.23\end{array}$ \\
\hline 7 days & 3 & - & $\begin{array}{c}1.2 \times 10^{2} \\
* 3.22\end{array}$ & $\begin{array}{c}1.8 \times 10^{2} \\
* 3.41\end{array}$ & $\begin{array}{l}2.2 \times 10^{2} \\
* 3.0\end{array}$ \\
\hline 14 days & - & 2 & No isolation & No isolation & No isolation \\
\hline 28 days & No increase & No increase & No isolation & No isolation & No isolation \\
\hline
\end{tabular}

lony forming units per $1 \mathrm{ml}$ of the medium - CFU/ml). The Saburo medium was plated with Candida yeast fungi, the nutrient agar - with Pseudomonas aeruginosa, and the egg yolk high salt agar culture medium - with Staphylococcus aureus. The thioglycolic acid medium was kept in thermostat at the temperature of $35^{\circ} \mathrm{C}$ for three days.

All bacterial cultures corresponded to taxonomic designation of the strain, and morphology of cultured colonies and cell morphology in microscopy were typical. The thioglycolic acid medium met the requirements for sterility - the growth of microorganisms was absent, the medium was transparent.

For the testing purpose a required number of suitable test microorganisms was added to the drug sample that was in the container, and the inoculated samples were stored at the corresponding temperature. At regular intervals the inoculated samples were sampled, and the microbial count was determined. The effectiveness of preservatives in the finished product is considered to be satisfactory if under conditions of the test while storing the inoculated samples at a given temperature during the given periods of time there is significant decrease or no increase in the microbial count depending on the requirements for the finished product.

\section{Results and Discussion}

According to Table 1 in 28 days of incubation while culturing in the thioglycolic acid medium the growth of microorganisms in the gel sample No. 5 was observed. Thus, it has been proven that addition of a preservative is required.
At the next step in order to select the optimal preservative (the samples mentioned above) the study was conducted for determining the microbiological purity. It has been found that sample No. 1 meets the criterion "B" in contrast to other samples meeting the criterion " $\mathrm{A}$ ".

As can be seen from Table 2, the preservative complex of sodium benzoate with Nipagin that meets the criterion " $\mathrm{A}$ " has the best preserving action.

The data given in Table 2 show that in 7 days of incubation the logarithm of the number of viable fungal cells was 3 . There is no cells isolation in 14 and 28 days of incubation. In 2 days of incubation the logarithm of the microbial plate count was 2.02 and 2.23 . On day 7 it was 3.22 and 3.41. On days $14^{\mathrm{h}}$ and 28 of incubation microorganisms were not recorded. The study of this sample has shown that it meets the criterion "A" in accordance with the SPhU requirements. Thus, the preservative complex of sodium benzoate with Nipagin has been selected for further studies.

\section{CONCLUSIONS}

1. As a result of the microbiological study it has been found that addition of a preservative to the gel with essential oils developed for treating diseases of the upper respiratory tract is mandatory.

2. It has been proven that all samples with the preservatives selected, namely methylparaben, the complex preservative "Germaben", sodium benzoate, and the complex of sodium benzoate with Nipagin, meet the criteria "A" and "B" of the SPhU. The preservative complex of sodium benzoate with Nipagin that meets the criterion "A" has the best preserving action.

\section{REFERENCES}

1. Бактеріологічний контроль пожсивнх середовищу. Інформаціійний лист МОЗ Украӥни №05.4.1 / 1670. K., 2001. -10 c.

2. Беликов О.Е., Пучкова Т.В. Консерванты в косметике и средствах гигиены. - М.: Школа косметических химиков, 2003. -250 c.

3. Гудзь О.В., Анисимова Ю.А., Яловенко Е.И. // Провизор. - 2000. - №12. - С. 38-39.

4. Державна фармакопея Украйни / Державне підприсмство «Науково-експертний фармакопейний ичентр». 1-е вид. - Х.: РІРЕГ, 2001. - 301 c. 
5. Лебединеиь О.В. Розробка складу та технологї стоматологічного гелю комплексної дї: дис. ... канд. фармац. наук: 15.00.01. - Х., 2012. - 146 c.

6. Павх О.І. Розробка складу та технологї̈ назальної мазі на основі рослинних настойок та ефірних олій: дис. ... канд. фармац. наук: 15.00.01. - Тернопіль, 2010. - 188 с.

7. Пуль В.В., Баранова I.І., Осолодченко Т.П. // Сучасні аспекти медицини і фармацї: зб. тез Всеукр. наук.-практ. конф. молодих учених та студентів за міжнар. участю. - Запоріжжя, $15-16$ травня, 2014. - C. 190.

8. Balk E.M., Zucker D.R., Engels E.A. et al. // J. Gen. Intern. Med. - 2001. - Vol. 16, №701. - P. 11.

9. Karlowsky J.A., Draghi D.C., Thornsberry C. et al. // Int. J. Antimicrob. Agents. - 2002. - Vol. 20, №178. - P. 76-85.

10. Rieger M.M., Banker G.S. - New York: Marcel Dekker. - 1989. - Vol. 10, №156. - P. 345.

ОБГРУНТУВАННЯ ВИБОРУ КОНСЕРВАНТА ПРИ РОЗРОБЦІ ГЕЛЮ 3 ЕФІРНИМИ ОЛІЯМИ ДЛЯ ЛІКУВАННЯ ЗАХВОРЮВАНЬ ВЕРХНІХ ДИХАЛЬНИХ ШЛЯХІВ

\section{В.В.Пуль-Лузан, О.П.Стрілець, Т.В.Мартинюк}

Ключові слова: консервант; гель з ефрірними оліями; мікробіологічна чистота; методика оцінки ефрективності консервантів

На теперішній час відмічається тенденція до використання лікарських препаратів зовнішньої дії з високим вмістом водної фази (креми о/в, гелі). Однак дані засоби є сприятливим середовищем для розвитку мікроорганізмів (культури S. aureus, Ps. aeruginosa) або псування готової продукції. У результаті проведених комплексних досліджень нами було розроблено склад гелю з ефрірними оліями для лікування захворювань верхніх дихальних шляхів. У зв'язку з тим, що розроблений гель повинен бути стабільним, у тому числі за показником мікробіологічної чистоти впродовж не менше 2-х років, потрібне вивчення мікробіологічної чистоти розробленого гелю та вибір при необхідності консерванту та його оптимальної концентрації. Відомо, що при виборі консерванту слід обов'язково звертати увагу на терапевтичну дію препарату, ділянку його нанесення, можливість взаємодії з іншими інгредієнтами рецептури, його розчинність. 3 урахуванням проведеного літературного пошуку з метою вибору ефективного консерванту (або їх комбінації), який би гарантував якість і безпечність розробленого гелю з ефрірними оліями, нами було вивчено антимікробну активність експериментальних зразків гелів з різними консервантами. Для досліджень було обрано такі консерванти: натрію бензоат, метилпарабен (ніпагін, метиловий ефір п-гідроксибензойної кислоти), а також комплекс натрію бензоату з ніпагіном. Також досліджувався комплексний консервант «Гермабен», до складу якого входять діазолідинілсечовина, метилпарабен, пропілпарабен у пропіленгліколі. Проведені дослідження показали, що комплекс консервантів натрію бензоату з ніпагіном має найкращу консервуючу дію та відповідає критерію «А» згідно з вимогами ДФУ.

\section{ОБОСНОВАНИЕ ВЫБОРА КОНСЕРВАНТА ПРИ РАЗРАБОТКЕ ГЕЛЯ С ЭФИРНЫМИ МАСЛАМИ ДЛЯ ЛЕЧЕНИЯ ЗАБОЛЕВАНИЙ ВЕРХНИХ ДЫХАТЕЛЬНЫХ ПУТЕЙ} В.В.Пуль-Лузан, О.П.Стрелец, Т.В.Мартынюк

Ключевые слова: консервант; гель с эфирными маслами; микробиологическая чистота; методика оценки эфффективности консервантов

В настоящее время отмечается тенденция к использованию лекарственных препаратов наружного действия с высоким содержанием водной фразы (кремы м/в, гели). Однако данные средства являются благоприятной средой для развития микроорганизмов (культуры S. aureus, Ps. Aeruginosa) или порчи готовой продукции (культуры плесневых грибов, дрожжеподобные грибы рода Candida). В результате проведенных комплексных исследований нами был разработан состав геля с эфирными маслами для лечения заболеваний верхних дыхательных путей. В связи с тем, что разработанный гель должен быть стабильным, в том числе по показателю микробиологической чистоты на протяжении не менее 2-х лет, необходимы изучение микробиологической чистоты разработанного геля и выбор оптимального консерванта и его концентрации. Известно, что при выборе консерванта необходимо обращать внимание на терапевтическое действие препарата, участок его нанесения, возможность взаимодействия с другими ингредиентами рецептуры, его растворимость. Учитывая проведенный литературный поиск с целью выбора эффективного консерванта (или их комбинации), который бы гарантировал качество и безопасность разработанного геля с эфирными маслами, нами была изучена антимикробная активность экспериментальных образцов гелей с различными консервантами. Для исследований были выбраны такие консерванты: натрия бензоат, метилпарабен (нипагин, метиловый эфир n-гидроксибензойной кислоты), а также комплекс натрия бензоата с нипагином. Также исследовался комплексный консервант «Гермабен», в состав которого входят диазолидинилмочевина, метилпарабен, пропилпарабен в пропиленгликоле. Проведенные исследования показали, что комплекс консервантов натрия бензоата с нипагином оказывает наилучшее консервирующее действие и отвечает критерию «А» соответственно требованиям ГФУ. 